\title{
Spontaneous and induced abortion trends and determinants in the Northeast semiarid region of Brazil: a transversal series
}

\author{
Luciano Lima Correia 1 \\ Hermano Alexandre Lima Rocha 2 \\ Álvaro Jorge Madeiro Leite 3 \\ Jocileide Sales Campos 4 \\ Anamaria Cavalcante e Silva 5 \\ Márcia Maria Tavares Machado 6 \\ Sabrina Gabriele Maia Oliveira Rocha 7 \\ Thales Nogueira Gomes 8 \\ Antônio José Ledo Alves da Cunha 9
}

1,2,7,8 Departamento de Saúde Comunitária. Faculdade de Medicina. Universidade Federal do Ceará. Rua Prof. Costa Mendes, 1608, $5^{\circ}$ andar. Rodolfo Teófilo. Fortaleza, CE, Brazil. CEP: 60.430-130. E-mail: hermano@ufc.br

3 Departamento de Pediatria. Faculdade de Medicina. Universidade Federal do Ceará. Fortaleza, CE, Brazil.

4,5 Centro Universitário UniChristus. Fortaleza, CE, Brazil.

6 Universidade Federal do Ceará. Fortaleza, CE, Brazil.

9 Departamento de Pediatria. Faculdade de Medicina. Universidade Federal do Rio de Janeiro. Rio de Janeiro, RJ, Brazil.

\begin{abstract}
Objectives: this study intends to estimate the rates, associated factors and trends of selfreported abortion rates in the northeast of Brazil.

Methods: series of population-based surveys realized in Ceará, northeast of Brazil, one of the poorest states in the country. A sample of about 27,000 women of reproductive age was used. Abortion was assessed according to women's information and rates were calculated using official population estimates. The trends and the association among socioeconomic and reproductive factors were studied using regressive models.

Results: a trend for reduction in rates was identified. For induced abortion, the determinants were: not having a partner, condom in the last sexual intercourse, first child up to 25years old $(A O R=5.21 ; A C I: 2.9-9.34)$ and having less than 13years old at first sexual intercourse $(A O R=5.88 ; A C I: 3.29-10.51)$. For spontaneous abortion were: having studied less than 8 years, knowledge and use of morning-after pill (AOR=26.44; ACI: 17.9-39.05) and not having any children $(A O R=3.43)$.

Conclusions: rates may have been low due to self-reporting. Young age and knowledge about contraceptive methods were associated to both kinds of abortion, while education level along with spontaneous and marital status with induced. Programs to reduce abortion rates should focus on single younger women with low education.
\end{abstract}

Key words Women health, Abortion rate, Prevalence study, Brazil, Epidemiologic determinants 


\section{Introduction}

The Millennium Development Goals (MDG) of World Health Organization (WHO), were a global effort to fight poverty in its multiple dimensions. One of its objectives was to improve maternal health by reducing on three quarters the maternal mortality rates between 1990 and 2015.1 Despite the decrease in maternal mortality by almost half worldwide in this period, the MDG did not achieve its goal and the number of death is still high, particularly in developing countries. ${ }^{2}$ Abortions and its complications are among the leading causes of maternal mortality in these settings and measuring its occurrence is an important form of monitoring and assessing its burden to the health system and to women's health. 2

In 2015, the United Nations launched the 2030 Agenda for Sustainable Development, a post-MDG action plan to reduce poverty worldwide. The abortion issue remains relevant in this document and is contemplated in the goal 3: To ensure healthy lives and promote well-being for all at all ages, in which it is highlighted the need of reducing maternal mortality and to improve access to sexual and reproductive health services. ${ }^{3}$

Abortion is a major issue on the subject of breach of human rights and women empowering currently discussed in society. The need for scientific studies on the subject, therefore, is imperative. However, due to the sensitive nature of the subject, the source of data is often limited and there are many difficulties obtaining them, especially the occurrence of induced abortion. ${ }^{4}$ Besides the negative physical consequences to women, abortion involves other negative effects, including increased financial burden to the health system 5 and to the family, stigmatization and psychosocial impact on women who underwent abortion. ${ }^{6}$ As of 2008, 4.4 million abortions occurred in Latin America, of which 95\% were considered unsafe. Most countries within this region have restricted laws that forbid abortion in most circumstances. Whereas stricter laws on this matter have not been associated with lower abortion rates, they are associated with a higher proportion of these abortions happening in inadequate settings and assisted by unskilled personnel, which poses risks to women and contributes to maternal mortality increase. ${ }^{7}$

This study aims to estimate rates, determinants and trends of abortion rates in the state of Ceará, northeast of Brazil from 1994 to 2007.

\section{Methods}

This study is part of a series of population-based surveys, conducted in the State of Ceará, Northeast of Brazil, which investigated a representative sample of women in reproductive age and preschool children in 1987, 1990.1994, 2001 and 2007. Full description in Correa et al. ${ }^{8}$ The data presented in this article, refer to the years 1994, 2001 and 2007, when data on abortion were collected.

Ceará is characterized as one of the poorest states in the country, with a semi-arid climate, which covers $95 \%$ of its territory, and a population of 8.2 million inhabitants. Social security benefits (pensions) and government (grants) provided to families, have become the most stable source of income to the population of the countryside, substantially ensuring the functioning of the economy of this region.

The series of cross-sectional studies surveyed a representative sample of the population of women in reproductive age, in the age group 10 to 49 years. In each study we applied the technique of cluster sampling, using census tract and stratification between the capital, Fortaleza, and the interior of the state. Census tracts result from the division of each municipality in geographic areas of variable length, though with a uniform population of around 300 families. The sample size, estimated at 8,000 households, representing about 35,000 people and 9,000 women with 10 to 49 years old, was initially established in the first study in 1987, and maintained on the subsequent ones including those in 1994, 2001 and 2007.

The primary outcome was the occurrence of abortion in the 12 months preceding the interview, reported by women of reproductive age.

We analyzed the following variables that were potentially associated to abortion occurrence: age (10 to 19 years, 20 to 29 years, 30 to 39 years, 40 to 49 years); parity (no children, one child, two children, three children or more); education(0-4 years, 5 to 8 years, 9 to 11 years, 12 or more); place of residence (capital or interior); marital status (having a partner, yes/no); sanitary conditions: satisfactory (households with piped water and flush toilet), intermediate (households with running water or flush toilet), unsatisfactory (households without piped water and flush toilet).

Data were entered twice using EpiInfo (CDCWHO) and statistically analyzed using SPSS 17 for Windows. Abortion rates were estimated by dividing the absolute number of reported abortion (numerator) to the women population of Ceará State 
(denominator) and then multiplying by 1,000 . We also calculated three other indicators: (i) percentage of induced abortions: number of induced abortions divided by the total number of abortions by 100 ; (ii) the Abortion Ratio: number of abortions, spontaneous or induced, per 100 live births; and (iii) the Induced Abortion Ratio: number of induced abortions per 100 spontaneous abortions. The temporal trends of theses rates were studied with linear regression models. We then studied the association between socioeconomic (age, education, place of residence, sanitary conditions)and reproductive (parity, marital status) factors to abortion rates, in each study period, using the simple logistic regression models with statistical significance level set on $5 \%$. Variables with $\mathrm{p}$ value of less than 0.1 were studied altogether in a multivariate logistic regression model. Graphs were built to represent adjusted odds ratios with a logarithmic scale.

All surveys were approved by the ethics committee of the institutions involved, the Brazilian Ministry of Health, the Ceará State Secretary of Health and the Federal University of Ceará. All participants signed an informed consent form before entering the study.

\section{Results}

We studied 9,713 women with 10 to 49 years of age in 1994, 9,733 in 2001 and 8,830 in 2007. Response rate was above $98 \%$ in all surveys. Of these women, about $60 \%$ had already had some childbearing experience, with at least one pregnancy. The absolute number of abortions was 158, 100 and 93 cases in 1994, 2001 and 2007, respectively (Table 1).

The proportion of pregnancies that ended in spontaneous abortions remained stable in the three study periods $(p=0.854)$. However, the proportion of induced abortions continued this pattern of stability only until 2001 , with ratios around $4.5 \%$, falling in 2007 to $1.1 \%$, but without statistical significance $(p=0.375)$. The general abortion ratio showed a similar pattern ( $p=0.343$ ) (Table 2$)$.

We found the following variables to be determinants $(p<0.001)$ of practicing an induced abortion: women age from 10 to 19 years old $(\mathrm{OR}=23.60$; CI 5.08 - 109.5), having a partner $(\mathrm{OR}=4.6$; CI: $2.51-8.45)$, women aged up to 13 years old at first sexual intercourse $(O R=7.1$; CI:0.88 -57.0), age of first pregnancy up to 14 yo (OR: 1.82; CI: 0.23 - 14.38), not having any children (OR: 13.12; CI: 4.29 - 40.09). Having used condom during last sexual intercourse (OR: 2.74; CI: $1.24-6.05)$ was also determinant of induced abortion $(p=0.013)$. A high proportion of women who underwent an induced abortion (86.8\%) did not attend a single antenatal care (ANC) visit and this was determinant $(p=0.032)$ of occurrence of induced abortion (OR: 1.97; CI: 0.47 - 8.25). Other determinants were not considered to be statistically significant. Details for each variable are listed on Table 3.

As for spontaneous abortion, these were found to be determinants of the occurrence of spontaneous abortion $(p<0.001)$ : women's age $10-19(\mathrm{OR}=$ 6.79; CI: $3.9-11.83)$, age up to 14 yo when had first offspring ( $\mathrm{OR}=2.65$; CI: $1.41-4.96)$ and not having any children $(\mathrm{OR}=14.95$; $\mathrm{CI}$ : $7.6-29.37)$. Being 10 years old or less at menarche $(\mathrm{OR}=2.76$; $\mathrm{CI}$ : $0.72-$ $10.52)$ and knowing/having used the morning-after pill $(\mathrm{OR}=2.2$; $\mathrm{CI}: 1.13$ - 4.29) were also determinants of having a spontaneous abortion ( $p=0.008$ and $p=0.002$, respectively). Full data for the other variables and groups can be found in Table 4.

In the multivariate analysis, women who wanted at least one additional offspring $(\mathrm{AOR}=3.45$; $\mathrm{ACI}$ : $2.34-5.09$ for IA and $\mathrm{AOR}=3.81$; ACI: $2.61-5.58$ for $\mathrm{SA}$ ) and aged up to 19 yo $(\mathrm{AOR}=2.54$; $\mathrm{ACI}$ : 1.65 - 3.91 for IA and AOR=13.47; ACI: $8.99-10.19$ for SA) were determinants to higher odds of both induced and spontaneous abortion $(p<0.001)$. For induced abortion, the groups found to be

Table 1

Number of spontaneous and induced abortions, induced percentages and abortion ratio. Ceará, 1994-2007.

\begin{tabular}{lrrr}
\hline & 1994 & 2001 & 2007 \\
\hline Total number of abortions & 158 & 100 & 93 \\
Number of spontaneous abortions & 117 & 69 & 86 \\
Number of induced abortions & 41 & 31 & 7 \\
Percentage of induced abortions* & 25.9 & 31.0 & 7.5 \\
Induced abortion ratio** & 35 & 45 & 8 \\
\hline
\end{tabular}

* Proportion of all abortion episodes; ** induce abortion per 100 spontaneous abortions. 
determinants of higher odds were not having a partner $(\mathrm{AOR}=3.79$; $\mathrm{ACI}$ : $2.5-5.75)$, having used condom in the last sexual intercourse $(\mathrm{AOR}=1.95$; ACI: $1.31-2.92)$, having had the first child up to 25 years old $(\mathrm{AOR}=5.21$; $\mathrm{ACI}: 2.9-9.34)$ and being less than $13 y$ at first sexual intercourse $(\mathrm{AOR}=$ 5.88; ACI: 3,.9 - 10.51). Finally, the following variables were determinants of spontaneous abortion: having studied less than 8 years $(\mathrm{AOR}=$ 166; ACI: $1.11-2.49$ ), knowledge and use of morning after pill $(\mathrm{AOR}=26.44$; $\mathrm{ACI}: 17.9-39.05)$ and not having any children $(\mathrm{AOR}=3.43$; $\mathrm{ACI}: 2.97$ - 6.59). Table 5 shows the complete multivariate analysis findings and the variables included in each model.

\section{Table 2}

Percentage of pregnancies ending in abortions and Abortion Ratios. Ceará, 1994-2007.

\begin{tabular}{lrrcc}
\hline & 1994 & 2001 & 2007 & $p$ \\
\hline \% of pregnancies ending in abortions* & & & & \\
Spontaneous abortions & 12.5 & 10.2 & 13.8 & \\
Induced abortions & 4.4 & 4.6 & 1.1 & \\
All abortions & 16.9 & 14.8 & 15.0 & \\
Abortion Ratios* & & & & \\
Spontaneous abortions & 15.1 & 12.0 & 16.3 & 0.854 \\
Induced abortions & 5.3 & 5.4 & 1.3 & 0.375 \\
All abortions & 20.4 & 17.4 & 17.6 & 0.343 \\
\end{tabular}

* An estimate of pregnancies in the previous 12 months, including births and abortions; **Abortions per 100 livebirths.

Table 3

\begin{tabular}{|c|c|c|c|c|c|}
\hline Factors & $\begin{array}{c}\text { Sample } \\
\text { proportion } \\
(\%)\end{array}$ & $\begin{array}{l}\text { Prevalence of } \\
\text { induced } \\
\text { abortion (\%) }\end{array}$ & Odds Ratio & $\mathrm{Cl} 95 \%$ & $p$ \\
\hline \multicolumn{6}{|c|}{ Literate women } \\
\hline Yes & 88.4 & 0.2 & 1.31 & $0.51-3.34$ & \\
\hline No & 11.6 & 0.3 & 1 & & 0.568 \\
\hline \multicolumn{6}{|c|}{ Has companion } \\
\hline Yes & 50.0 & 0.2 & 4.60 & $2.51-8.45$ & \\
\hline No & 50.0 & 1.1 & 1 & & $<0.001^{\dagger}$ \\
\hline \multicolumn{6}{|c|}{ Women age (years) } \\
\hline 10 to 19 & 20.9 & 1.5 & $2 ., 60$ & $5.08-10.50$ & \\
\hline 20 to 29 & 46.5 & 0.6 & 9.82 & $2.29-42.07$ & $<0.001^{\dagger}$ \\
\hline 30 to 39 & 27.9 & 0.3 & 4.94 & $1.10-22.12$ & \\
\hline 40 to 49 & 4.7 & 0.1 & 1 & & \\
\hline \multicolumn{6}{|c|}{ Years of schooling } \\
\hline Up to 4 & 2.3 & 0.2 & 0.50 & $0.46-5.60$ & \\
\hline 5 to 8 & 74.4 & 0.5 & 1.29 & $0.31-5.42$ & 0.432 \\
\hline 9 to 12 & 18.6 & 0.3 & 0.73 & $0.15-3.43$ & \\
\hline 13 to 16 & 4.7 & 0.4 & 1 & & \\
\hline \multicolumn{6}{|c|}{ Age of menarche (years) } \\
\hline Up to 10 & 7.0 & 1.0 & 3.08 & $0.31-29.77$ & \\
\hline 11 to 12 & 37.2 & 0.5 & 1.39 & $0.18-10.57$ & 0.688 \\
\hline 13 to 14 & 41.9 & 0.4 & 1.25 & $0.16-9.44$ & \\
\hline 15 to 16 & 11.6 & 0.3 & 0.89 & $0.10-7.64$ & \\
\hline 19 and on & 2.3 & 0.3 & 1 & & \\
\hline
\end{tabular}


Induced abortions determinants.

\begin{tabular}{|c|c|c|c|c|c|}
\hline Factors & $\begin{array}{c}\text { Sample } \\
\text { proportion } \\
(\%)\end{array}$ & $\begin{array}{l}\text { Prevalence of } \\
\text { induced } \\
\text { abortion (\%) }\end{array}$ & Odds Ratio & $\mathrm{Cl} 195 \%$ & $p$ \\
\hline \multicolumn{6}{|c|}{ Age at first sexual intercourse(years) } \\
\hline Up to 13 & 18.6 & 1.6 & 7.10 & $0.88-5700$ & \\
\hline 14 to 17 & 53.5 & 0.5 & 2.37 & $0.32-17.61$ & $<0.001^{+\dagger}$ \\
\hline 18 to 25 & 25.6 & 0.2 & 1.03 & $0.13-8.00$ & \\
\hline 25 to 35 & 2.3 & 0.2 & 1 & & \\
\hline \multicolumn{6}{|c|}{ Use contraceptive methods } \\
\hline Yes & 61.5 & 0.5 & 0.83 & $0.43-1.59$ & \\
\hline No & 38.5 & 0.5 & 1 & & 0.585 \\
\hline \multicolumn{6}{|c|}{ Had sexual intercourse the last 30 days? } \\
\hline Yes & 59.5 & 0.3 & 0.56 & $0.30-1.05$ & \\
\hline No & 40.5 & 0.6 & 1 & & 0.073 \\
\hline \multicolumn{6}{|c|}{ Used condom in the last sexual intercourse } \\
\hline Yes & 38.5 & 0.7 & 2.74 & $1.24-6.05$ & \\
\hline No & 61.5 & 0.3 & 1 & & $0.013^{\dagger}$ \\
\hline \multicolumn{6}{|c|}{ Knows the morning-after pill } \\
\hline Yes and used & 7.0 & 0.8 & 1.79 & $0.54-5.89$ & \\
\hline Yes & 23.3 & 0.3 & 0.66 & $0.32-1.36$ & 0.280 \\
\hline Doesn't know & 69.8 & 0.4 & 1 & & \\
\hline \multicolumn{6}{|c|}{ Number of pregnancies } \\
\hline One & 26.2 & 0.4 & 1.18 & $0.46-3.07$ & \\
\hline 2 to 4 & 57.1 & 0.4 & 1.12 & $0.48-2.62$ & 0.938 \\
\hline 5 or more & 16.7 & 0, & 1 & & \\
\hline \multicolumn{6}{|c|}{ Age of first pregnancy (years) } \\
\hline Up to 14 & 23.3 & 1.9 & 1.82 & $0.23-14.38$ & \\
\hline 15 to 17 & 34.9 & 0.6 & 0.54 & $0.07-4.14$ & $<0.001^{\dagger}$ \\
\hline 18 to 25 & 34.9 & 0.2 & 0.23 & $0.03-1.75$ & \\
\hline 26 to 35 & 4.7 & 0.2 & 0.14 & $0.01-1.65$ & \\
\hline 36 or more & 2.3 & 1.0 & 1 & & \\
\hline \multicolumn{6}{|c|}{ Age when had first child (years) } \\
\hline Up to 14 & 6.9 & 0.5 & 6.63 & $0.60-73.35$ & \\
\hline 15 to 17 & 34.5 & 0.5 & 6.74 & $0.86-52.75$ & 0.162 \\
\hline 18 to 25 & 55.2 & 0.2 & 3.52 & $0.46-26.58$ & \\
\hline 26 to 35 & 3.4 & 0.1 & 1 & & \\
\hline \multicolumn{6}{|c|}{ Number of children } \\
\hline None & 3.6 & 3.5 & 1.12 & $4.29-40.09$ & \\
\hline One & 25.6 & 0.4 & 1.40 & $0.44-4.40$ & $<0.001^{\dagger}$ \\
\hline 2 to 4 & 32.6 & 0.2 & 0.86 & $0.28-2.3$ & \\
\hline 5 or more & 9.3 & 0.3 & 1 & & \\
\hline \multicolumn{6}{|l|}{ Wanted the child } \\
\hline Yes & 35.5 & 0.2 & 0.50 & $0.24-1.04$ & \\
\hline No & 64.5 & 0.4 & 1 & & 0.066 \\
\hline \multicolumn{6}{|c|}{ How many more children intended } \\
\hline None & 44.2 & 0.2 & 0.12 & $0.05-0.26$ & \\
\hline One & 34.9 & 0.8 & 0.40 & $0.17-0.92$ & $<0.001^{\dagger}$ \\
\hline 2 to 4 & 20.9 & 1.9 & 1 & & \\
\hline \multicolumn{6}{|c|}{ How many antenatalcare visits in last pregnancy } \\
\hline None & 86.8 & 0.7 & 1.97 & $0.47-8.25$ & \\
\hline 1 to 3 & 7.9 & 3.6 & 10.66 & $1.75-64.82$ & $0.032^{\dagger}$ \\
\hline 7 or more & 5.3 & 0.4 & 1 & & \\
\hline
\end{tabular}

${ }_{\dagger}$ Included in model; ${ }^{\dagger+}$ Not included in model for collinearity. 
Table 4

Spontaneous abortion determinants.

\begin{tabular}{|c|c|c|c|c|c|}
\hline Factors & $\begin{array}{c}\text { Sample } \\
\text { proportion } \\
(\%)\end{array}$ & $\begin{array}{l}\text { Prevalence of } \\
\text { induced } \\
\text { abortion (\%) }\end{array}$ & Odds Ratio & $\mathrm{Cl} 95 \%$ & $p$ \\
\hline \multicolumn{6}{|l|}{ Literate women } \\
\hline Yes & 87.4 & 1.5 & 1.20 & $0.75-1.92$ & 0.443 \\
\hline No & 12.6 & 1.3 & 1 & & \\
\hline \multicolumn{6}{|l|}{ Has companion } \\
\hline Yes & 80.5 & 1.5 & 1.10 & $0.74-1.64$ & 0.611 \\
\hline No & 19.5 & 1.6 & 1 & & \\
\hline \multicolumn{6}{|c|}{ Women age (years) } \\
\hline 10 to 19 & 18.4 & 4.8 & 6.79 & $3.90-11.83$ & $<0.001^{\dagger}$ \\
\hline 20 to 29 & 35.4 & 1.7 & 2.40 & $1.47-3.91$ & \\
\hline 30 to 39 & 31.6 & 1.3 & 1.79 & $1.09-2.95$ & \\
\hline 40 to 49 & 14.6 & 0.7 & 1 & & \\
\hline \multicolumn{6}{|c|}{ Years of schooling } \\
\hline Up to 4 & 4.4 & 1.3 & 0.78 & $0.29-2.12$ & 0.194 \\
\hline 5 to 8 & 55.1 & 1.3 & 0.78 & $0.39-1.55$ & \\
\hline 9 to 12 & 34.8 & 1.9 & 1.12 & $0.55-2.29$ & \\
\hline 13 to 16 & 5.7 & 1.7 & 1 & & \\
\hline \multicolumn{6}{|c|}{ Age at menarche (years) } \\
\hline Up to 10 & 5.0 & 2.6 & 2.76 & $0.72-10.52$ & $0.008^{\dagger}$ \\
\hline 11 to 12 & 45.3 & 2.0 & 2.11 & $0.66-6.75$ & \\
\hline 13 to 14 & 35.8 & 1.3 & 1.33 & $0.41-4.27$ & \\
\hline 15 to 16 & 11.3 & 1.0 & 1.06 & $0.31-3.65$ & \\
\hline 17 to 18 & 0.6 & 0.3 & 0.33 & $0.03-3.19$ & \\
\hline 19 and on & 1.9 & 1.0 & 1 & & \\
\hline \multicolumn{6}{|c|}{ Age of first sexual intercourse (years) } \\
\hline Up to 13 & 5.9 & 1.7 & 0.98 & $0.37-2.57$ & $0.024^{\dagger}$ \\
\hline 14 to 17 & 5.9 & 1.9 & 1.05 & $0.50-2.19$ & \\
\hline 18 to 25 & 34.9 & 1.1 & 0.61 & $0.29-1.30$ & \\
\hline 25 to 35 & 5.3 & 1.8 & 1 & & \\
\hline \multicolumn{6}{|c|}{ Use contraceptive methods } \\
\hline Yes & 65.3 & 1.8 & 1 & & 0.072 \\
\hline No & 34.7 & 1.3 & 0.70 & $0.48-1.03$ & \\
\hline \multicolumn{6}{|c|}{ Had sexual intercourse the last 30 days? } \\
\hline Yes & 75.0 & 1.6 & 1.16 & $0.81-1.66$ & 0.408 \\
\hline No & 25.0 & 1.3 & 1 & & \\
\hline \multicolumn{6}{|c|}{ Used condom in the last sexual intercourse } \\
\hline Yes & 22.0 & 1.9 & 1.23 & $0.80-1.89$ & 0.340 \\
\hline No & 78.0 & 1.5 & 1 & & \\
\hline \multicolumn{6}{|c|}{ Knows the morning-after pill } \\
\hline Yes and used & 6.3 & 2.6 & 2.20 & $1.13-4.29$ & $0.002^{\dagger}$ \\
\hline Yes & 42.5 & 2.0 & 1.66 & $1.20-2.30$ & \\
\hline Doesn't know & 51.2 & 1.2 & 1 & & \\
\hline \multicolumn{6}{|c|}{ Number of pregnancies } \\
\hline One & 22.6 & 1.4 & 1.18 & $0.70-2.00$ & 0.240 \\
\hline 2 to 4 & 62.9 & 1.6 & 1.43 & $0.91-2.26$ & \\
\hline 5 or more & 14.5 & 1.1 & 1 & & \\
\hline
\end{tabular}

† Included in model; ${ }^{\dagger+}$ Not included in model for collinearity. 


\begin{tabular}{|c|c|c|c|c|c|}
\hline Factors & $\begin{array}{c}\text { Sample } \\
\text { proportion } \\
(\%)\end{array}$ & $\begin{array}{l}\text { Prevalence of } \\
\text { induced } \\
\text { abortion (\%) }\end{array}$ & Odds Ratio & $\mathrm{Cl} 195 \%$ & $p$ \\
\hline \multicolumn{6}{|c|}{ Age at first pregnancy (years) } \\
\hline Up to 14 years & 5.0 & 1.5 & 0.27 & $0.08-0.86$ & $<0.0011^{\dagger}$ \\
\hline 15 to 17 & 35.0 & 2.1 & 0.39 & $0.15-1.00$ & \\
\hline 18 to 25 & 41.3 & 1.1 & 0.19 & $0.07-0.49$ & \\
\hline 26 to 35 & 15.6 & 2.0 & 0.36 & $0.13-0.97$ & \\
\hline 36 or more & 3.1 & 5.2 & 1 & & \\
\hline \multicolumn{6}{|c|}{ Age when had first child (years) } \\
\hline Up to 14 & 13.1 & 4.2 & 2.65 & $1.41-4.96$ & $<0.001^{\dagger}$ \\
\hline 15 to 17 & 24.1 & 1.6 & 0.96 & $0.56-1.64$ & \\
\hline 18 to 25 & 46.0 & 1.0 & 0.59 & $0.37-0.96$ & \\
\hline 26 to 35 & 16.8 & 1.6 & 1 & & \\
\hline \multicolumn{6}{|c|}{ Number of children } \\
\hline None & 25.9 & 10.2 & 14.95 & $7.60-29.37$ & $<0.001^{\dagger}$ \\
\hline One & 33.5 & 1.8 & 2.47 & $1.29-4.76$ & \\
\hline 2 to 4 & 33.5 & 0.9 & 1.19 & $0.62-2.29$ & \\
\hline 5 or more & 7.0 & 0.8 & 1 & & \\
\hline \multicolumn{6}{|l|}{ Wanted the child } \\
\hline Yes & 57.1 & 1.5 & 1.22 & $0.87-1.70$ & 0.247 \\
\hline No & 42.9 & 1.2 & 1 & & \\
\hline \multicolumn{6}{|c|}{ How many more children intended } \\
\hline None & 37.5 & 0.7 & 0.11 & $0.07-0.17$ & $<0.001^{\dagger}$ \\
\hline One & 43.8 & 3.5 & 0.55 & $0.35-0.86$ & \\
\hline 2 to 4 & 18.8 & 6.2 & 1 & & \\
\hline \multicolumn{6}{|c|}{ How many antenatal care visits in last pregnancy } \\
\hline None & 88.2 & 1.4 & 1.33 & $0.57-3.09$ & 0.481 \\
\hline 1 to 3 & 1.3 & 1.2 & 1.14 & $0.13-9.66$ & \\
\hline 4 to 6 & 2.6 & 0.5 & 0.47 & $0.09-2.35$ & \\
\hline 7 or more & 7.9 & 1.1 & 1 & & \\
\hline
\end{tabular}

$\uparrow$ Included in model; ${ }^{\dagger \dagger}$ Not included in model for collinearity.

Table 5

Multivariate logistic regression.

\begin{tabular}{|c|c|c|c|}
\hline Variable & Adjusted OR & Adjusted $\mathrm{Cl}$ & $p$ \\
\hline \multicolumn{4}{|l|}{ Induced abortion* } \\
\hline Doesn't have companion & 3.79 & $2.50-5.75$ & $<0.001$ \\
\hline Used condom in the last sexual intercourse & 1.95 & $1.31-2.92$ & 0.001 \\
\hline Wants one or more additional child & 3.45 & $2.34-5.09$ & $<0.001$ \\
\hline Age at first offspring up to 25 years-old & 5.21 & $2.90-9.34$ & $<0.001$ \\
\hline Women's age up to 19 years-old & 2.54 & $1.65-3.91$ & $<0.001$ \\
\hline Age at first sexual intercourse up to 13 years-old & 5.88 & $3.29-10.51$ & $<0.001$ \\
\hline \multicolumn{4}{|l|}{ Spotaneous abortion** } \\
\hline Schooling up to 8 years & 1.66 & $1.11-2.49$ & 0.013 \\
\hline Knew and had already used morning-after pill & 26.44 & $17.90-39.05$ & $<0.001$ \\
\hline Want one or more other child & 3.81 & $2.61-5.58$ & $<0.001$ \\
\hline Women age up to 19 years-old & 13.47 & $8.99-20.19$ & $<0.001$ \\
\hline Doesn't have children & 4.43 & $2.97-6.59$ & $<0.001$ \\
\hline
\end{tabular}




\section{Discussion}

It was identified a tendency of decrease in the abortion rates, but without statistical significance. The main independent determinant factors found in this study were education, maternal age and age of first sexual relation, knowledge about contraceptive methods, parity, and marital status.

It is worth noting, however, that the abortion cases analyzed in this study were reported and, as it is a sensitive issue, there is almost certainly an underestimation of its occurrence, both the total number of cases, as well as cases in which the women admitted to have been induced, and this can create an information bias if the expositions reporting is dependent of the occurrence of abortion. In addition, we did not calculate the sample size to study the associations because there were no reliable prevalence data for that. However, the study has important strengths such as being population based and having used similar methodology in all surveys, allowing us to study the evolution of variables and associations over time, especially in Brazil, where there are very little data about this issue.

Our data showed the evolution of abortion rates in Ceará over a period of thirteen years, indicating a drop in the $90 \mathrm{~s}$ as well as in the beginning of the new millennium, but since then, it has remained markedly unchanged. Thus, while in 1994 the overall rate of abortions was 16 cases per 1,000 women, in 2001 and 2007 the rate suffered a reduction of $38 \%$, stabilizing at 10 cases per 1,000 women.

Education was associated with the abortion rates and other studies, in different Brazilian regions, have found similar results, with the probability of pregnancy ending in induced abortion being higher in women with more years of schooling. $9,10 \mathrm{~A}$ possible explanation to this is that women with higher education levels might have better decision making skills and knowledge, therefore, are more empowered to induce abortion than their counterparts with fewer years of schooling. This effect was controlled for the effect of the family income.

The role of early initiation of sexual life is particularly alarming. Young people do not often use contraceptive methods in their first sexual intercourse and, as a consequence, a large number of unintended pregnancies happen within the first year of sexual activity. ${ }^{11,12}$ The issue with this is that adolescents and young women often appeal on abortion as an alternative to the social and economic consequences of being a single mother and raising a child. ${ }^{13}$ In countries like the United Kingdom, the percentage of pregnancies that end in abortion are as high as $44 \%$ in women under 18 years old and $61.8 \%$ in those 16 and under. ${ }^{14}$

Young maternal age is a well-known risk factor for spontaneous abortion, beyond that, the means in which abortion occurs among young women is also important, since unsafe abortion is more frequent in this group when compared to older women. This might be due to the feeling of fear and shame experienced by these women, as well as difficulties in access to health services or lack of financial resources. ${ }^{13,15}$ This supports our finding that although younger maternal age was associated to both spontaneous and induced abortion, the odds were much higher for the second group.

Although the number of abortions and the abortion rate fell in the studied period in all age groups, both among women with previous childbearing experience and among adolescents, the latter age group had the highest abortion rates. Young age and null parity were the main associated factors to abortion. This is in accordance with other studies that found that young women aged 20 to 29 years-old and adolescents are the most vulnerable to induced abortion in Brazil.9,10 Therefore, earlier pregnancies are an important and complex piece of the abortion matter and approaches to tackle it should be focused in this group age.

Although guaranteed to every women by the government, regular access to contraceptive methods is still not a reality for a large proportion of Brazilian women, especially to those with lowest income and users of the public health system.16,17 This means that there is a considerable unmet demand for contraceptives: women in childbearing age whose last or current pregnancy was unintended. 18

Besides the direct effect of unmet demand on unwanted pregnancies and induced abortion, adequate use of contraceptive methods is closely linked to women education level, which means that women with better education have the necessary knowledge to choose the method that best fits her and therefore to use it consistently. 19

Another important finding in our study is the association of induced abortion with not having a partner. The same association was not found for spontaneous abortion. It is well known that when single woman become pregnant, they are more likely to choose abortion than the married women.20 Studies in other continents and in other Brazilian states show that pregnancy among single women are more likely to end in induced abortion.21-23 This might be due to the fact that many of the single 
women are in their first years of sexual activity and in this period the sexual intercourse are often occasional and multiple with lower prevalence of use of contraceptives. ${ }^{24}$ Besides, women may lack the autonomy to decide the means in which the sexual intercourse takes place, with men often refusing to use condoms leading to unintended pregnancies. 25 This means that measures to improve contraceptive use and empower women might help to tackle this problem.

We observed that age and parity stood out as the most strongly associated factors to abortion. It is important to note that age and parity are directly correlated in the sense that the younger the woman, the more likely to have fewer children or no children. Studies that discriminated the types of abortion found that young age and low parity were important risk factors for induced abortions, 26,27 whereas advanced age was a major risk factor for spontaneous abortions. 28,29

The observation that abortion is not associated with the conditions of living in a big city or a small town, or living with or without a steady partner, or with a favorable economic situation, reinforces the premise that the focus of any program to reduce abortion rates should be on younger age group of women with childbearing experience.

It should be considered that many of the compared countries have legalized procedure, so the equalization of rates can mean some level of underestimation in our rates, due to the fact that they are self-reported.

\section{References}

1. Bhutta ZA, Chopra M, Axelson H, et al. Countdown to 2015 decade report (2000-10): taking stock of maternal, newborn, and child survival. Lancet (London, England). 2010; 375 (9730): 2032-44.

2. United N. Millennium development goals report 2015. [Place of publication not identified]: United Nations Pubns; 2015 .

3. Howell MD, Ngo L, Folcarelli P, et al. Sustained effectiveness of a primary-team-based rapid response system. Critical care medicine. 2012; 40 (9): 2562.

4. Bankole A, Singh S, Haas T. Reasons why women have induced abortions: evidence from 27 countries. Int Fam Plann Perspect. 1998: 117-52.

5. Johnston HB, Gallo MF, Benson J. Reducing the costs to health systems of unsafe abortion: a comparison of four strategies. J Fam Plann Reprod Health Care. 2007; 33 (4): 250-7.

6. Major B, Cozzarelli C, Cooper ML, Zubek J, Richards C, Wilhite M, Gramzow RH. Psychological responses of
New researches should be conducted, attempting to reduce methodological problem such as the underestimation of abortion rates. Besides, new researches are needed, with a cultural perspective, to test strategies aiming to reduce the problem on the target groups identified. Although our data are only for women, men's responsibility for contraception has been discussed in the literature, 30 and new studies identifying the male determinants that lead to the occurrence of abortion should be conducted, especially for comparison with women's factors.

In conclusion, there was a drop in abortion rates in the studied period, although not statistically significant. Young age and parity were strongly associated to abortion. Being a single mother was associated to induced abortion but not to spontaneous. The abortion issue in Ceará, as everywhere else, is complex and multifaceted. There is no silver bullet to solve it, however, programs to reduce abortion rates should focus on younger women with no childbearing experience. Continuing surveillance and research efforts are also of utmost importance to plan strategies and assess progress made in this serious public health issue. Based on our results, it is clear that a program to reduce abortion rates in the population should be concentrated primarily in young women, especially those who have started their sexual life. The fact that abortion rates are two times higher among more educated women, compared to those with up to four years of study, certainly leads to a greater expected impact from any educational campaign. women after first-trimester abortion. Arch Gen Psychiatry. 2000; 57 (8): 777-84.

7. Alan Guttmacher I. Facts in brief : induced abortion worldwide. New York: The Institute; 1989.

8. Correia LL, Silva AC, Campos JS, Andrade FMO, Silveira DMI, Machado MMT, Cunha AJLA. Metodologia das Pesquisas Populacionais de Saúde Materno-Infantil: uma série transversal realizada no Estado do Ceará de 1987 a 2007. Rev Bras Saúde Mater Infant. 2014; 14: 353-62.

9. Brazil, Secretaria de Ciência TeIE, Departamento de Ciência e T. Aborto e saúde pública no Brasil : 20 anos. Brasília, DF: Ministério da Saúde, Secretaria de Ciência, Tecnologia e Insumos Estratégicos, Departamento de Ciência e Tecnologia; 2009.

10. Fusco CLB, Andreoni S, Silva RdSe. Epidemiologia do aborto inseguro em uma população em situação de pobreza Favela Inajar de Souza, São Paulo. Rev Bras Epidemiol. 2008;11:78-88. 
11. McCauley AP, Salter C, Kiragu K, Senderowitz J. Meeting the needs of young adults. Population Reports J. 1995 (41) $1-43$.

12. Zabin LS, Kantner JF, Zelnik M. The risk of adolescent pregnancy in the first months of intercourse. Fam Plann Persp. 1979; 11 (4): 215-22.

13. Bledsoe $\mathrm{CH}$, Cohen B, Working Group on the Social Dynamics of Adolescent F. Social dynamics of adolescent fertility in Sub-Saharan Africa. 1993.

14. Association FP. Teenagers: sexual health and behaviour factsheet. [Factsheet]. 2011; http://www.fpa.org.uk/factsheets/teenagers-sexual-health-behaviour\#fCqi. [Accessed 08/06, 2016].

15. Hirsch JS, Barker G, International Forum on Adolescent F. Adolescents and unsafe abortion in developing countries : a preventable tragedy : based on the proceedings from the International Forum on Adolescent Fertility. Washington, D.C.: Center for Population Options, International Center on Adolescent Fertility; 1992.

16. Brasil. Ministério da Saúde. Secretaria de Políticas de S. Assistencia em planejamento familiar: manual tecnico. Brasilia, DF; 2002.

17. Brasil. Ministério da Saúde. PORTARIA N ${ }^{\circ}$ 426/GM em 22 de março de 2005. Institui, no âmbito do SUS, a Política Nacional de Atenção Integral em Reprodução Humana Assistida e dá outras providências. Brasilia, DF; 2005.

18. Tavares LS. Demanda total por anticoncepção no Brasil: uso e necessidade insatisfeita por métodos anticoncepcionais [dissertação]. Rio de Janeiro: Escola Nacional de Saúde Pública Sérgio Arouca- Fiocruz; 2006.

19. Fusco CLB, Silva RdSe, Andreoni S. Unsafe abortion: social determinants and health inequities in a vulnerable population in São Paulo, Brazil. Cad Saúde Pública. 2012; 28: 709-19.

20. Bankole A, Singh S, Haas T. Características de mulheres que obtêm aborto induzido: uma revisão a nível mundial. Perspect Int Planej Fam. 2001; (Spec): 10-9.
21. Rogo KO. Induced abortion in sub-Saharan Africa. East Afr Med J. 1993; 70 (6): 386-95.

22. Andreoni S, de Souza R, Silva JD. Quem está mais propensa a recorrer ao aborto provocado diante de uma gravidez indesejada? Estudo com mulheres em idade fértil residentes em três regiões da cidade de São Paulo (SP), Brasil. Reprod Climaterio. 2012; 27: 58-64.

23. Silva RdS, Andreoni S. Fatores associados ao aborto induzido entre jovens pobres na cidade de São Paulo, 2007. Rev Bras Estud Popul. 2012.

24. Souza e Silva R. Patterns of induced abortion in urban area of Southeastern region, Brazil. Rev Saúde Pública. 1998; 32 (1): 7-17.

25. Golding JM, Wilsnack SC, Learman LA. Prevalence of sexual assault history among women with common gynecologic symptoms. Am J Obstet Gynecol. 1998; 179 (4): 1013-9.

26. Skjeldestad FE, Borgan J-K, Daltveit AK, Nymoen EH. Induced abortion: effects of marital status, age and parity on choice of pregnancy termination. Acta Obstet Gynecol Scand. 1994; 73 (3): 255-60.

27. Megafu U, Ozumba B. Morbidity and mortality from induced illegal abortion at the University of Nigeria Teaching Hospital, Enugu: a five year review. Int J Gynecol Obstet. 1991; 34 (2): 163-7.

28. Coste J, Job-Spira N, Fernandez H. Risk factors for spontaneous abortion: a case-control study in France. Hum Reprod. 1991; 6 (9): 1332-7.

29. Risch HA, Weiss NS, Clarke EA, Miller AB. Risk factors for spontaneous abortion and its recurrence. Am J Epidemiol. 1988; 128 (2): 420-30.

30. Brown S. 'They think it's all up to the girls': gender, risk and responsibility for contraception. Cult, Health Sex. 2015;17 (3): 312-25.

Received on November 10, 2016

Final version presented on August 14, 2017

Approved on December 12, 2017 